\title{
LEGAL FRAMEWORK ON THE EVALUATION OF THE EFFECTIVENESS OF REGIONS IN FOREING COUNTRIES \\ Umidullaev Qahramon,
}

A doctoral candidate at the Academy of Public Administration under the President of the Republic of Uzbekistan

Crossref

Issue DOI http: / / dx.doi.org/10.26739/2433-202x-2017-12-12

c Article DOI http:/ / dx.doi.org/10.26739/2433-202x-2017-12-12-12

\section{Annotation}

The article focuses on evaluation of the effectiveness of over public administration authorities. Moreover, the article covers transparency, openness and evaluation of effectiveness of functions public administration authorities. Moreover, the article covers the issues of evaluations effectiveness assessment and developing methods of evaluation and its transparency.

Key words: Public administration authorities, evaluation of effectiveness, local government, governor, region, district, city.

At the present time, a systematic set-up of the focus on effectiveness in the work of radical improvement of performance in the local authorities as well as in all spheres of state and society, requires effective evaluation on the basis of specific criteria. This method is currently being developed and put into practice by many countries in the world taking into consideration their state structure and other aspects of their existence.

The State Services Commissioner carries out the evaluation of senior civil servants in New Zealand. An essential measure of efficiency analysis is interviewing. The benchmark criteria include the contributions of leaders to the achievement of the goals of public authorities, but also to the development of public services and their effectiveness. The head of the public service commission has the right to regulate the issue of remuneration of Umidullaev Qahramon 
employees. For example, if he finds it desirable, he can award more than 15\% of his annual salary [1].

In South Korea, where a management system for the year 2006 is set, the efficiency assessment system in Korea focuses primarily on identifying the most successful leaders. 360 degrees of excellence are used to evaluate the effectiveness of public servants in senior positions. This method should be considered not only by the manager, but also from the staff members of the team. This method serves to pay for civil servants' salaries. The results of this method may also be based on the transfer of employees to another level of promotion or dismissal [2].

Relevant benchmarks and indicators are required for identifying management outcomes and evaluating the results. In some western countries, such indicators are developed by research centers. For example, the scientific center was founded in 1913 in the United States. In 1949, a Bureau for Management Efficiency was established. The Commission on the Effectiveness of Civil Service operated under the President of the United States. Until 1978, a National Center for Public Sector Management Studies was established. There are currently a few such centers in the United States. scientific experiments have been accumulated on the basis of an efficient state body. Leading universities in the world, as well as by many international organizations, have contributed to the organization of effective public administration [3].

In the region and in Russia as a whole, there is a growing disability level of population. Disability annually appropriated to $4-5$ thousand people of all ages. The main causes of disability in the adult population of the Tomsk region are diseases of the circulatory system (25.5\%), malignant neoplasms $(22.8 \%)$, diseases of the musculoskeletal system and connective tissue $(8.3 \%)$. Considering this demographic factor, besides investing in the prevention of disability, they should actively create jobs for people with disabilities [4].

In particular, in the Russian Federation since 2006 the criteria for evaluating the effectiveness of regional development have been elaborated and improved from year to year.

In particular, on August 21, 2012, the Decree of the President of the Russian Federation "On the Assessment of the Effectiveness of Executive Power of the Russian Federation" was adopted. In the decree the executive power bodies have reduced the list of indicators of efficiency evaluation. Every year the Decree and other documents of the President of the Russian Federation are adopted to improve the efficiency assessment mechanism in the regions. On November 14, 2017, on improvement of system and Umidullaev Qahramon 
assessment methodologies in the Decree of the President of the Russian Federation "On Assessment of the Performance of the Executive Bodies in the Russian Federation".

The Foundation for Civil Society Development in the Russian Federation will study the effectiveness of the work of public authorities and governance bodies, including regional, district and city authorities(khokimiyats), on the basis of established criteria and will be evaluated on a 100-point scale on a quarterly basis. This system assesses the effectiveness of managers' work.

For this purpose, the Decree of the President of the Russian Federation "On the Assessment of the Effectiveness of the Activity of the Russian Federation's Executive Bodies" dated August 21, 2012, No. 1199 was adopted. Associate Professor of the Tombov branch of the Academy of Public Administration and Public Service under the President of the Russian Federation Y. Trifonov presented his report on "Legal and methodological aspects of assessment of efficiency in the executive branch of the Russian Federation" [5].

In the Russian Federation

- life expectancy

- Number of population

- The size of the investment in the main capital

- Activities of small businesses and individual entrepreneurs, including turnover of goods (services) by small businesses,

- Total tax and non-tax revenues

-Unemployment Rate,

- real income of the population

- provision of housing and communal services

- quality and effectiveness of education

- Death and its causes,

- the level of living standards,

-based on the criteria for 12 main and 43 other sectors, such as working with orphans, guardians and children with care left without parental care. The system is being improved every year since 2006 .

In the United Kingdom, an agreement on the effectiveness of the performance of managerial personnel is first made. The main sections of the agreement on the effectiveness of the public servant in the list are as follows[6]:

- key areas of responsibility;

- objectives, criteria of efficiency; Umidullaev Qahramon 
- commentary indicating "achievement of the goal" or "failure to achieve the goal";

- knowledge and skills;

- half-yearly report;

- individual development plan, including criteria for admission.

The assessment takes place twice a year and at the end of the year. At the end of the year, the staff member completes a self-employed form. In addition to self-evaluation, in some cases colleagues and staff members, the results of surveys from government consumers, which are provided by the public authority, are taken into account[7].

The use of a comprehensive assessment (the "360 degree" method) increases the credibility of the decision taken and the objectivity of the ordinary and public service providers and the key management of government services in the assessment process.

By the end of the year, each ministry is divided into four groups of civil servants, each of which has a good position [ $\left.{ }^{8}\right]$ :

- the first group - the best of the $25 \%$ assessed;

- the second group - the next $40 \%$ of the evaluated;

- the third group - the next $20-25 \%$ of the evaluated;

- fourth group - at least $5-10 \%$ of the evaluated.

Direct evaluations of the assessors provide recommendations on increasing the salaries of government employees and awarding them to the payroll committee at the Senior Civil Service Pay Committee. The maximum amount of awards should not exceed $20 \%$ of the annual salary.

The team that has been included in the least effective group develop professional growth programs for the services provided.

There is no formal requirement for the Canadian Effectiveness Agreement - the departments and agencies have full freedom to plan and achieve results. Nevertheless, there are a number of sections that must be included in the effectiveness agreement. These include[ [9]:

- start and end dates of the works cycle;

- current obligations and efficiency criteria;

- key responsibilities and performance criteria;

- achieved results (completed at the end of the work cycle);

- written assessment (completed upon completion of work cycle).

The outcome arrangements are usually from 4 up to 7 current (budgeting), human resources management, and operational management of scheduling programs. Principal obligations changes from year to year in

\section{Umidullaev Qahramon}


accordance with the priorities of the public body. There are 1 to 3 main responsibilities for the plan period.

There is no official monitoring of the efficiency of civil servants in Canada. The assessment process is carried out by the Secretariat (Privy Council Office). The final assessment of efficiency is the assessment made by the state service providers that they have fulfilled their obligations under the effectiveness agreement.

In order to improve the objectivity of the process, these self-evaluation results are filled in with survey data from senior officials. For example, the evaluation of the Deputy Minister shall include the following $\left[{ }^{10}\right]$ :

- Recommendation given by the head of the person being assessed;

- Comments by the assessed administrator of the main agencies accountable for the use of financial and personnel resources, such as Treasury Board Secretariat and Public Service Agency;

- recommendations from the last person who has left this position;

-Comments from the Committee on Senior Officials dealing with the selection of staff for senior positions.

The head is assigned one of the levels of assessment based on the results of the state duty. The distribution of these groups is usually done in the following proportions.

There is no clear link between Canadian employment scoring results and growth in service rankings. However, there is no doubt about the successful performance of the staff in decision-making. The optimal proportion of civil service groups in the Canada category.

In the case of low profitability of employees in the workforce, there is no strict sanctions for them. In this case, productivity assessmentfocus only on the areas of their professional development.

There is a need to develop clear criteria for evaluating the effectiveness of their activities in order to make basic conclusions on the activities of public administration bodies. As long as management's evaluates the performance of the management, each person comes from his or her subjective opinion. On the other hand, the elaboration of the criteria for the effectiveness of the activities of state power bodies creates an opportunity for objective and impartial assessment on the one hand and, on the other hand, the elimination of contradictory boxes among the members of the society and the resulting contradictions.

In scientific literature, if you look at this point, the Bulgarian scientist M.Markov points out to the term "criterion" and considers it as a characteristic of the event or phenomenon, its character, its classification[11] Umidullaev Qahramon 
Indeed, the evaluation criteria allow evaluating the activities of local authorities, identifying the nature of local government, and classifying it qualitatively.

It should be noted that the origin of socio-economic problems in the localities and their expansion is often due to the weakness, lack of competence, irresponsibility of the local government and the lack of proper governance. The First President of the Republic of Uzbekistan, Islam Karimov, emphasized the two needs for the leaders to address this issue. "The first requirement is to radically change the responsibility of each managing director to his job, to increase personal responsibility ... The second issue is to have relevant knowledge and experience and to be highly qualified. .. Russian knows it is "competent". That is, being a complacent person in his own field is the demand of time. In other words, it is necessary to be master of his work, to know the secrets of his sphere in all respects. We evaluate and summarize how each leader's work meets these two challenges. I'm more concerned about the first one, the more important it is to take responsibility. The knowledge of the guide is not enough; it can be learned. But if he forgets about obligation and responsibility, there will be no shift or change from work [12]

This implies that, first of all, the managerial staff of the local authorities implements effective work management and the introduction of wisely management. Effective management helps solve or prevent problems. This involves a thorough, comprehensive study of the individual, group and social interests in society, the analysis and the satisfaction of these interests with the utmost utilization of available resources. Undoubtedly, the current problems can not be resolved in a timely manner, and timely implementation of the decisions can lead to negative consequences.

The socio-economic criteria of management efficiency give possibility to the problems in society and the extent to which they are solved by local authorities.

In addition, the socio-economic benefits of governance will be assessed not only for continued activities, but also for the further development of the achieved results. Russian scientist G. A. Atamanchuk, who has been studying a number of criteria for the effectiveness of government governance, introduces the effectiveness of governance as an public benchmark:

- efficiency of production, conformity to generally accepted standards;

- scale and rate of increase of national wealth;

- order of social relations, safety and reliability, indicators of socioeconomic growth;

Umidullaev Qahramon 
- the level of welfare calculated by the distribution of per capita income $\left[{ }^{13}\right]$.

Estimation of effectiveness on a rating system on defined criteria creates healthy competition in the regions. Regular information on each area is advanced and what is behind it. In the future, it will be possible to plan works on this basis, to develop a network that is behind it. Leaders have a creative approach to day-to-day works, the full and effective use of existing opportunities in the regions, and incentives to use new areas of socioeconomic development. The system will be more effective in the example of our people, who are proud of our mentality or who are proud of everything else, and who do not care to stay behind.

The rating system for performance evaluation does not mean that leaders can be blamed on such things as dependency, indifference, selfishness. They can not ignore any of the areas listed in the evaluation criteria. In the regions, all areas are guaranteed to develop at the same time, without leaving behind one another. This, in turn, creates a basis for the comprehensive development and prosperity of our state.

The system broadens the capabilities of each sector individually based on criteria. Efficiency recognition engagements not only work in the system, but also contribute to the development of the country by creating an environment of healthy competition in these regions. Evaluation criteria should be developed and developed annually, taking into account the interests of the state and the entire population. At the same time, it is important to reduce the gap between the poorer population, the proportion of people in the regions, as well as the reduction of the number of unemployments by creating new jobs, employment, raising the activeness of the citizens, and establishing an active business environment.

It is also important that the system is further expanded by the fact that the administrative command line is still far from extending an inefficient old management system, such as planning and managing all business. Administrators ensure that they do not have to wait for the command from above. Emphasizing the effectiveness of the position and the role of the service, it encourages its creative approach and creates a basis for further development of responsibility for the development of the region and new initiatives. The system creates a realistic basis for each leader, especially for the governors, to have a clear understanding of the issues of functioning of public administration bodies and other organizations and institutions in the area of their leadership. They have qualities such as leadership and initiative. Without the practical results in the case, self-defense with fake statistical Umidullaev Qahramon 
records can create opportunities for the practice of dealing with unhealthy situations.

Assessment is more appropriate for the purpose of each region, taking into account the specific, unique conditions and capabilities. Given the current capacities of the work in each region, it will be necessary to identify and plan areas that require attention, taking into account the most important needs of the population. In this context, taking into account the views of the people in the area, in turn, increases their social activity. It also helps to ensure timely and quality of planned work. It is well known that in many countries of the world are being effectively used in various forms of public oversight mechanisms, such as working with the public, taking into account the views of citizens in public administration. 


\section{REFERENCES}

1 New Zealand State Services Commission: http://www.ssc.govt.nt

2 Pan. Suk. Kim// Transforming Higher level Civil Service in a New Age: A Case Study of a Civil Service in Korea // Public Personal Management.2007.Vol.36. № 2. Summer 2007. -pp. 127-139.

3 I.E.NikulinaI.V.Khomenko. Interdependence of Demographic and Economic Development of Regions, Volume 166, January 2015, pp.-142-146. https://www.sciencedirect.com/science/article/pii/S1877042814066373

4 Bourn M., Neely A., Mills J. и Platts K. Implementing performance measurement systems: a literature review Int. J. Business Performance Management, Vol. 5, No. 1, 2003: 1-24.

5 Trifonov Yuri Nikolaevich Ph.D., Associate Professor, Tambov branch of the Russian Academy of National Economy and Public Administration under the President of the Russian Federation. Evaluation of the effectiveness of executive bodies of the subjects of the Russian Federation: legal and methodological aspects:, Tambov, Russia.

http://www.политуправление.pф

6 KetelaarA., Manning N., Turkish E. (2007). Performance-based Arrangements for Senior Civil Servants OECD and other Country Experiences // OECD Working Papers on Public Governance, OECD Publishing. 2007. № 5. Pp. 28 -59.

7 Performance Management Guidance 2008/09 for Senior Secretaries and the Senior Civil Service. Cabinet OfficeUK. http://www.pppaservies.qinentiqtim.com.

8 Performance Management Guidance 2008/09 for Senior Secretaries and the Senior Civil Service. Cabinet OfficeUK. http://www.pppaservies.qinentiqtim.com.

9 KetelaarA., Manning N., Turkish E. (2007). Performance-based Arrangements for Senior Civil Servants OECD and other Country Experiences // OECD Working Papers on Public Governance, OECD Publishing. 2007. № 5. Pp. 28 -59.

10 Performance Management Program Guidelines. Heads of Agencies and other Governor in Council. Appointees. Senior Personnel and Special Projects Secretariat. Privy Council Office, Canada. http://www.pcobcp.gc.ca. 11 Markov.M. Technology and effectiveness of social management. Ayer with the blog. M., -1982. - P. 112. 
12 Karimov. I.A. Uzbek people will never be dependent on anyone. -T "Uzbekistan" 1999.- B.439.

13 Atamanchuk. G. In the State Administration (organizational and functional issues). M .: OAO "NGO Economics". Encyclopedia of managerial knowledge. 2000. 260-6. 